\title{
Recovery of bone powder from salmon by- product and application in production of Tra catfish cake
}

\author{
Tam Dinh-Le Vo*, Chi Bao Vo, Huynh Thi Thuy Nguyen, Linh Truc Le, \\ Do Thong Trong Vi, Nguyen Thi Huong Thao
}

\begin{abstract}
In this study, salmon by-products were utilised to produce high ash content (AC) salmon bone powder (SBP) using hydrolytic enzyme and apply in the production of Tra catfish cake. The byproducts included $61.9 \%$ of moisture, $43.1 \%$ of protein, $45.4 \%$ of lipid, $10.2 \%$ of ash, $3.7 \%$ of calcium and $2.3 \%$ of phosphorus (on dry weight basis). The AC of SBP achieved the maximal value of 46.9\% when hydrolytic enzyme of Alcalase, $\mathrm{pH}$ value of 6.5, temperature of $600 \mathrm{C}$, the Enzyme/Substrate $(E / S)$ ratio of $60 \mathrm{U} / g$ protein and time of 4 hours. The obtained SBP contained $23.1 \%$ of calcium, $11.7 \%$ of phosphorus and without heavy metals such as cadmium, mercury and lead. The fish cake added with $2 \%$ of SBP owned the highest gel strength, folding score and whiteness of 287.4, AA and 65.3, respectively and it was accepted by the test panel. Hence, SBP could be used in the production of Tra catfish cake as a mineral supplement.
\end{abstract}

Index Terms - salmon bone powder, ash content, Tra catfish cake, calcium, phosphorus.

\section{INTRODUCTION}

$\mathrm{n}$ the recent years, the salmon farming industry has strongly developed in the world and the

Received: 06-12-2016, Accepted: 17-02-2017.

This research was funded by the Vietnam National University HoChiMinh city (VNU-HCM) under Grant number C2017-20-34

Tam Dinh-Le Vo, Chi Bao Vo, Huynh Thi Thuy Nguyen, Linh Truc Le, Do Thong Trong Vi - Faculty of Chemical Engineering, Ho Chi Minh City Univeristy of Technology Viet Nam National University Ho Chi Minh City.

Email: vdlt@hcmut.edu.vn

Nguyen Thi Huong Thao - Research Center for Aquafeed Nutrition and Fishery Post-harvest Technology Research Institute for Aquaculture No.2 huge amount of processing by-products is discarded. The utilisation of fish by-products to produce value-added products has attracted scientists. Salmon by-products were utilised to produce bioactive peptide with angiotensin converting enzyme and dipeptidyl peptidase IV inhibitory, and antioxidant activities [1]. Besides, scientists vastly interested in the bone fraction, which was a potential mineral source. Malde et al. (2010) [2] revealed that the ash and calcium contents of boiled salmon bone were $43 \mathrm{~g} / 100 \mathrm{~g}$ and $157 \mathrm{~g} / \mathrm{kg}$ dry weight, respectively. Calcium and phosphorus comprised $32.0 \%$ and $15.8 \%$ of Lesser sardine bones (Sardinella fimbriata), which were considered as an inexpensive raw material for the production of calcium tablets [3]. Hemung (2013) [4] recovered tilapia bone powder with soluble calcium ion concentration of $116.6 \mathrm{mg} / \mathrm{L}$ by using sodium hydroxide to hydrolyse tilapia bone while Nemati et al. (2016) [5] obtained tuna bone powder with calcium content of $38.2 \mathrm{~g} / 100 \mathrm{~g}$ from tuna bone using the same method.

Tra catfish cake was a popular protein-based product in Vietnam. It has been elucidated that the protein gel structure was improved by the presence of calcium due to the fact that calcium acts as a bridge connecting two adjacent proteins and that calcium also acts as a cofactor for the enzyme Transglutaminase catalysing the forming of protein cross-linking [6]. Therefore, adding bone powder containing calcium into the Tra catfish cake improved sensory property of the fish cake. Besides, along with the trend of fortifying some food products with bone powder such as bakery product supplied with tuna bone powder [5], the authors tried to enrich mineral for the fish cake in this research. 
The aim of this study is to produce SBP by using hydrolytic enzyme and utilize it as a mineral supplying additive to enhance the mineral content of Tra catfish cake.

\section{MATERIALS AND METHODS.}

\subsection{Materials}

\section{Salmon by-products}

The salmon frames including bones, fins, tails and some remaining flesh attached to the frames were provided by ANNASEA Fresh company in Ho Chi Minh city, Vietnam. The by-products were transported on ice to the Biochemical laboratory of Ho Chi Minh City Univeristy of Technology within 4 hours. The by-products were ground, vacuum packed in polyethylene bags and stored at $-20^{\circ} \mathrm{C}$ until used.

\section{Enzymes and chemicals}

Alcalase, Neutrase, Protamex, Flavourzyme and Corolase were obtained from Novozymes (Denmark) and AB enzymes (Germany). Working $\mathrm{pH}$ and temperature of these enzymes were presented in table 1. Chemicals were purchased from Sigma-Aldrich and Merck. All reagents were of analytical grade. Double-distilled water was used in experiments.

\subsection{Methods}

\section{Chemical analysis}

The contents of moisture, crude protein, crude fat and ash of the by-products were determined based on the methods of AOAC (2000) [7]. The total crude protein content was determined using Kjeldahl method with Nitrogen conversion factor of 6.25 .

The effects of enzyme type, E/S ratio and hydrolytic time on the $A C$ of the $S B P$

Concerning the effect of enzyme type, the salmon by-products were hydrolysed at optimal $\mathrm{pH}$ and temperature as shown as in table 1 . The $\mathrm{E} / \mathrm{S}$ ratio was $15 \mathrm{U} / \mathrm{g}$ protein and the hydrolytic time was 2 hours.

Relating to $\mathrm{E} / \mathrm{S}$ ratio, the by-products were hydrolysed using Alcalase, $\mathrm{pH}$ of 6.5 , temperature of $60^{\circ} \mathrm{C}$, hydrolytic time of 2 hours and the $\mathrm{E} / \mathrm{S}$ ratio was controlled from 15 to $75 \mathrm{U} / \mathrm{g}$ protein.

Regarding the effect of hydrolytic time, the by- products were hydrolysed by Alcalase at $60^{\circ} \mathrm{C}, \mathrm{pH}$ $6.5, \mathrm{E} / \mathrm{S}$ ratio of $60 \mathrm{U} / \mathrm{g}$ protein and hydrolytic time was from 1 to 5 hours.

Table 1. Optimal $\mathrm{pH}$ and temperature of enzymes

\begin{tabular}{lcc}
\hline \multicolumn{1}{c}{ Enzyme } & Optimal pH & Optimal Temperature \\
\hline Alcalase & 7.5 & $55^{\circ} \mathrm{C}$ \\
Neutrase & 8 & $55^{\circ} \mathrm{C}$ \\
Protamex & 6.5 & $55^{\circ} \mathrm{C}$ \\
Corolase & 7 & $55^{\circ} \mathrm{C}$ \\
Flavourzyme & 7 & $50^{\circ} \mathrm{C}$ \\
\hline
\end{tabular}

\section{Preparation of SBP}

For each batch, minced by-products were thawed. Then water was added with the ratio of water: by-product of $4: 1(\mathrm{v} / \mathrm{w})$. Next, the mixture was heated at $95^{\circ} \mathrm{C}$ for 10 minutes to deactivate endogenous enzymes and the $\mathrm{pH}$ value of the mixture was adjusted to the desired value before adding enzyme for hydrolysis. Hydrolysis temperature was controlled using a water bath (Memmert WB14, Germany) and $\mathrm{pH}$ value was monitored every 15 minutes using sodium hydroxide or hydrochloric acid solution of $0.1 \mathrm{~N}$. After the required hydrolysis time, the reaction was terminated by heating the proteolysates for 10 min at $90^{\circ} \mathrm{C}$ in order to deactivate hydrolysis enzyme. The hydrolysates were then centrifuged at $6,000 \times \mathrm{g}$ for 20 minutes and then cooled down to $4^{\circ} \mathrm{C}$ to separate the upper fat fraction. Next, the mixture was filtered through Whatman paper no. 3 to collect the residues containing bones. Then, the residues were washed twice with distilled water and dried at $70^{\circ} \mathrm{C}$.

\section{Detection of heavy metals in SBP}

Cadmium and lead content were determined based on AOAC official method 999.11. Test portions are dried before calcination at $450^{\circ} \mathrm{C}$ under a gradual increase in temperature $\left(\leq 50^{\circ} \mathrm{C} / \mathrm{h}\right)$. Then $6 \mathrm{M} \mathrm{HCl}$ is added and the solution is evaporated to dryness. The residue is dissolved in $0.1 \mathrm{M} \mathrm{HNO}_{3}$, and the samples are determined by flame and graphite procedures [7]. The presence of mercury was identified by AOAC official method 971.21 [7].

Preparation of Tra catfish cake 
$500 \mathrm{~g}$ of fillet Tra catfish was crushed in a silent cutter. Then the other ingredients including salt, sugar, monosodium glutamate, pepper, wheat flour, onion flour, additive and SBP with various proportions $(2 \%, 4 \%$ and $6 \%)$ were added and the mixture was ground and mashed to get homogenised paste. The homogenised paste was stuffed into a plastic tube with $18 \mathrm{~mm}$ in width and both ends of the tube were covered. The tube was placed in a water bath at $40^{\circ} \mathrm{C}$ in 20 minutes for gel forming. After that, it was cooked at $90^{\circ} \mathrm{C}$ for 20 minutes. Then, it was cooled immediately in cold water before storing at $4^{\circ} \mathrm{C}$ for 24 hours.

\section{Determination of gel strength by puncture test}

The puncture test was applied to determine gel strength. The test was performed between 24 and 48 hours. The gel strength was measured using a Texture Analyzer SUN RHEO TEX - Japan (model SD-700). A spherical plunger, $5 \mathrm{~mm}$ in diameter was dropped at the rate of $60 \mathrm{~mm} /$ minute [6]. The gel strength (GS) was determined by the following equation:

$$
\mathrm{GS}=\mathrm{L} \cdot \mathrm{h}(\mathrm{g} \cdot \mathrm{cm})
$$

Where $\mathrm{L}$ is the penetration force $(\mathrm{g})$ and $\mathrm{h}$ is the deformation at breakage $(\mathrm{mm})$.

\section{Whiteness}

The flat and smooth slices with $15 \mathrm{~mm}$ in thickness of Tra catfish cake were evaluated using a colour difference meter (Minolta CR-400 Chroma Meter, SunSientific, Japan) [6]. The whiteness was calculated as the following equation:

$$
w=100-\sqrt{(100-L)^{2}+a^{2}+b^{2}}
$$

Where $\mathrm{L}$ is the lightness, a is the red-green colour and $\mathrm{b}$ is the yellow-blue colour.

\section{Folding test}

The folding test of the fish cake was performed using the method of Darmanto et al. (2014) [8]. A $2 \mathrm{~cm}$ diameter and $0.5 \mathrm{~cm}$ thickness of Tra catfish cake was folded once into a semicircle or twice into a quadrant. The samples were assigned as follows: AA: No crack when it was folded into a quadrant, A: No crack when it was folded into a semicircle, B: Cracks when it was folded into a semicircle, C: Breaks into two pieces when it was folded into a semicircle.

\section{Sensory evaluation}

Sensory evaluation for the SBP-fortified fish cake was performed using the 7 point hedonic scale $(1=$ dislike extremely and $7=$ like extremely) to determine the consumer acceptability [9]. Sixty untrained panellists included students and staffs of Ho Chi Minh City Univeristy of Technology evaluated the overall acceptability of the samples.

\section{Statistical analysis}

Data were presented as means \pm standard deviations (SD) of triplicate determinations. Mean differences among the measurements were statistically significant at the $95 \%$ confidence level. Analysis of variance (ANOVA) was performed using the Statgraphics Centurion XV.

\section{RESULTS AND DISCUSSION.}

\subsection{Proximate composition analysis of salmon by products}

The salmon by-products in this study contained $58.5 \%$ of moisture, $43.1 \%$ of crude protein, $45.4 \%$ of crude lipid, $10.2 \%$ of ash, $3.7 \%$ of calcium and $2.3 \%$ of phosphorus (on dry weight basis). The AC of salmon by-products was lower than those of cod bone, tilapia bone and Tra catfish bone which were $28.5 \%, 26.7 \%$ and $15.8 \%$, respectively [10-12]. However, it was higher than that of silver catfish frame which was $7.1 \%$ [13]. Therefore, salmon byproduct was also a promising mineral supplement.

\subsection{Effect of enzyme type on the $A C$}

The effect of enzyme type on the AC of the SBP was presented in figure 1 . The $\mathrm{AC}$ reached the peak when the by-product was hydrolysed by Alcalase, followed by Protamex, Corolase, Flavourzyme and Neutrase. Aspmo et al. (2005) [14] also revealed that Alcalase was the best 
choice among Protamex, Bromelain, Papain, Neutrase when hydrolysing Atlantic cod viscera. In addition, Alcalase was used for hydrolysis of salmon muscle protein [15]. Thus, Alcalase was chosen as hydrolytic enzyme for the further analysis.

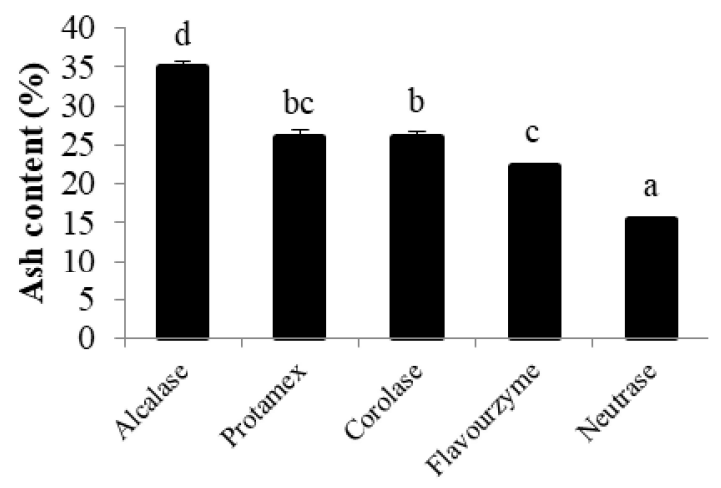

Enzyme type

Figure 1. The effect of enzyme type on the AC. Values represent the mean $\pm \mathrm{SD}$ of three determinations. Bars with different letters indicate significant differences $(\mathrm{P}<0.05)$.

\subsection{Effect of E/S ratio on the $A C$}

Figure 2 illustrates the result of effect of $\mathrm{E} / \mathrm{S}$ ratio on the $\mathrm{AC}$ of the $\mathrm{SBP}$. The $\mathrm{AC}$ slightly rose up when the E/S ratio increased from 15 to $75 \mathrm{U} / \mathrm{g}$ protein. It reached the peak of $42.3 \%$ at the $\mathrm{E} / \mathrm{S}$ ratio of $60 \mathrm{U} / \mathrm{g}$ protein. This indicated that peptide bonds were more extensively cleaved in the presence of a higher amount of enzyme.

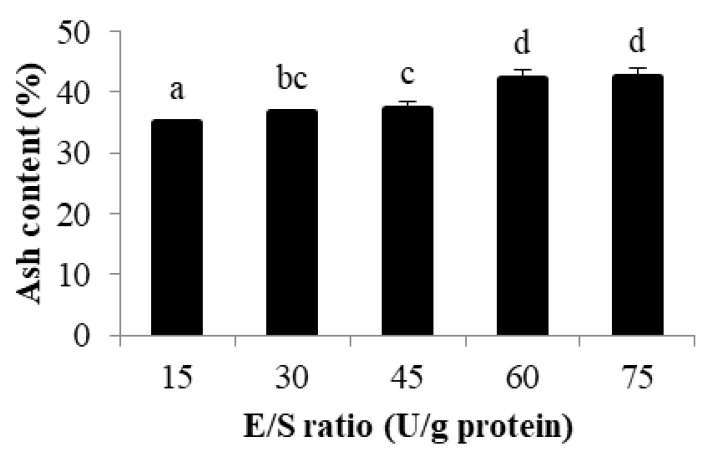

Figure 2. The effect of E/S ratio on the AC. Values represent the mean $\pm \mathrm{SD}$ of three determinations. Bars with different letters indicate significant differences $(\mathrm{P}<0.05)$

However, up to the certain amount of enzyme, all substrates bound to enzyme, thus there was no increase in the $\mathrm{AC}$ when the $\mathrm{E} / \mathrm{S}$ ratio continuously augmented. Similar result was observed in the study of Gbogouri et al. (2004) [16] who reported that the degree of hydrolysis was significantly high when using Alcalase to hydrolyse salmon byproducts with the E/S ratio of approximately 60 $\mathrm{U} / \mathrm{g}$ protein. Hence, $60 \mathrm{U} / \mathrm{g}$ protein was selected for the next investigation.

\subsection{Effect of hydrolysis time on the AC}

The figure 3 shows the findings of effect of proteolysis time on the AC of the SBP. When prolonging the hydrolytic time from 1 hour to 5 hours, the AC gradually increased from $35.2 \%$ to $47.8 \%$ and reached the peak at 4 hours. The rise in proteolysis time led to the increase in degree of hydrolysis, causing the better removal of the remaining flesh out of the bones and finally increase in the AC. This is consistent with the findings of Ovissipour et al. (2009) [17] who picked around 4 hours for hydrolysis Persian sturgeon fish viscera. Furthermore, Kechaou et al. (2009) [18] indicated that the highest degree of hydrolysis achieved at 4 hours of hydrolysis of sardine viscera with Alcalase. Thus, 4 hours was selected for proteolytic time.

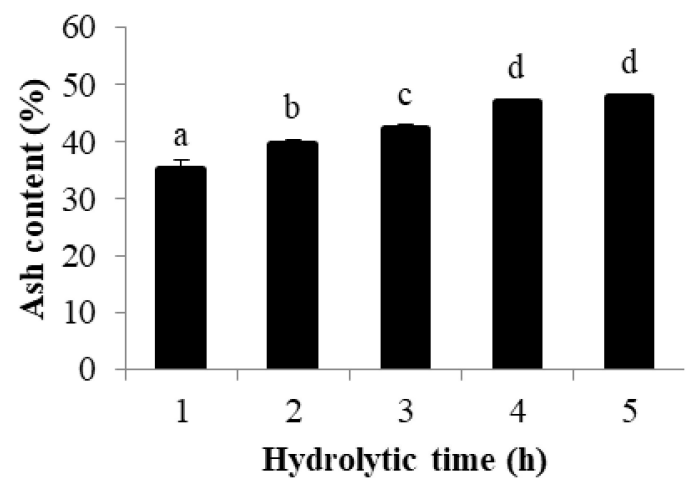

Figure 3. The effect of hydrolytic time on the AC. Values represent the mean $\pm \mathrm{SD}$ of three determinations. Bars with different letters indicate significant differences $(\mathrm{P}<0.05)$.

\subsection{Chemical composition of SBP}

The analysis result of some typical minerals of the SBP showed that it contained $23.1 \%$ of calcium and $11.7 \%$ of phosphorus. Heavy metals such as cadmium, mercury and lead were not detected. Calcium content of the SBP was slightly lower than those of hoki, giant seaperch and chicken bone powders, which were $31.8 \%, 28.1 \%$ 
and $32.2 \%$, respectively [19]. Additionally, the Ca:P ratio of the SBP was approximately 2:1 which was nearly the same as that of tuna bone powder obtained from tuna frame hydrolysed by sodium hydroxide [5]. This result indicated that the SBP has potential to be applied as a calcium fortificant in food products.

\subsection{Gel strength, folding test, whiteness and sensory evaluation of Tra catfish cake fortified with the SBP}

Table 2 demonstrated that the gel strength, folding score and whiteness of the fortified fish cake reached the peak of 287.4, AA and 65.3 when the the fish cake was added with $2 \%$ of SBP. The gel strength is a crucial factor for quality evaluation of protein-based product [6]. The folding test is used to evaluate elasticity which is an important sensory attribute of gel products. The AA value meant that the fish cake was extremely elastic [20].

The formation and properties of protein gels not were only highly depending on fish species, the quality and kind of fish flesh but also effected by ionic strength, $\mathrm{pH}$, temperature and other factors [21]. The addition of SBP which contains calcium may contribute to improve the gel strength due to the fact that the calcium ion may form ionic linkage between two adjacent proteins. In addition, calcium ions act as cofactor for the enzyme Transglutaminase. This enzyme catalyses the forming of protein cross-linking of proteins through the formation of covalent bonds between protein molecules, resulting in improving the gel strength [6]. In the case of fish cake fortified with $4 \%$ and $6 \%$ SBP (table 2), the statistically significant lowering of gel strength could be observed. The higher the amount of calcium ion could inhibit a uniform development of the protein network, causing negative effect on the gel strength [6].

The whiteness of fish cake depends on fish muscle colour, the kind of raw material and fish freshness. The analysis results indicate that the SBP influenced on the whiteness of the fish cake. This may be due to the remaining fat in the SBP. The overall acceptability score of the fish cake fortified with 2\% SBP showed the highest value of 4.4, which means the SBP-fortified fish cake was accepted by the test panellist. The features of SBP may contribute to the properties of the fish cake such as gel strength and elasticity without any unfavourable flavour or taste. Consequently, $2 \%$ of SBP was added to the Tra catfish cake to enhance its properties.

\section{CONCLUSIONS.}

SBP was first successfully produced from salmon by-products which is a natural and quite cheap source. Alcalase was the good enzyme to obtain the SBP with high ash content. The Tra catfish cake added with 2\% SBP enhanced gel strength without changing the whiteness, the folding score and the consumer acceptance. The SBP showed potential to be an alternative natural calcium supplement for food products.

Table 2. Analysis results of gel strength, folding test, whiteness and sensory evaluation

\begin{tabular}{ccccc}
\hline Sample & Gel strength (g.cm) & Folding score & Whiteness & Overall acceptability \\
\hline $\mathbf{0 \%}$ SBP & $213.94 \pm 29.38^{\mathrm{b}}$ & AA & $66.97 \pm 0.78^{\mathrm{c}}$ & $4.25 \pm 1.20^{\mathrm{a}}$ \\
$\mathbf{2 \%}$ SBP & $287.39 \pm 48.65^{\mathrm{c}}$ & AA & $65.25 \pm 0.49^{\mathrm{b}}$ & $4.37 \pm 1.22^{\mathrm{a}}$ \\
$\mathbf{4 \%}$ SBP & $241.68 \pm 31.72^{\mathrm{b}}$ & B & $64.47 \pm 0.53^{\mathrm{ab}}$ & $4.23 \pm 1.32^{\mathrm{a}}$ \\
$\mathbf{6 \%}$ SBP & $149.28 \pm 15.70^{\mathrm{a}}$ & C & $64.41 \pm 0.61^{\mathrm{a}}$ & $4.07 \pm 1.33^{\mathrm{a}}$ \\
\hline
\end{tabular}

Values represent the mean \pm SD of three determinations. The values in the same column with different letters indicate significant differences $(\mathrm{P}<0.05)$. 


\section{TÀI LIỆU THAM KHẢO}

[1]. Neves A.C., Harnedy P.A., O'Keeffe M.B., and FitzGerald R.J., Bioactive peptides from Atlantic salmon (Salmo salar) with angiotensin converting enzyme and dipeptidyl peptidase IV inhibitory, and antioxidant activities. Food Chemistry. 218, 396-405 (2017).

[2]. Marian K Malde, Susanne Bügel, Mette Kristensen, Ketil Malde, Ingvild E Graff, and Pedersen J.I., Calcium from salmon and cod bone is well absorbed in young healthy men: a doubleblinded randomised crossover design. Nutrition \& Metabolism. 7(61), 1-9 (2010).

[3]. Eugien X., Pravinkumar L.M., Logesh A.R., Viswanathan C., and Raffi S.M., Estimation of calcium and phosphorus in bones of three low value fishes Sardinella fimbriata, Sardinella albella and Sardinella gibbosa from Muttom, Southeast Coast of India. International Journal of Current Trends in Research 3(2), 43-46 (2014).

[4]. 4. Hemung B.-O., Properties of Tilapia Bone Powder and Its Calcium Bioavailability Based on Transglutaminase Assay. International Journal of Bioscience, Biochemistry and Bioinformatics. 3(4), 306309 (2013).

[5]. Nemati M., Kamilah H., Huda N., and Ariffin F., In vitro calcium availability in bakery products fortified with tuna bone powder as a natural calcium source. International Journal of Food Sciences and Nutrition. 67(5), 535-540 (2016).

[6]. Park J.W., Surimi and Surimi Seafood. 2013, Florida: CRC Press. 666.

[7]. AOAC, AOAC-Methods of Analysis. 2000, 15th ed. Washington, DC.

[8]. Darmanto Y.S., Agustini T.W., Swastawati F., and Bulushi I.A., The effect of fish bone collagens in improving food quality. International Food Research Journal. 21(3), 891-896 (2014).

[9]. Marina A.M. and NurulAzizah S., Use of Coconut Versus Dairy Milk Products in Malaysian Dishes: Comparison of Nutritional Composition and Sensory Evaluation. Journal of Food and Nutrition Research. 2(4), 204-208 (2014).

[10]. Gildberg A., Arnesen J.A., and Carleho"g M., Utilisation of cod backbone by biochemical fractionation, Process Biochemistry. Process Biochemistry. 38, 475-480 (2002).

[11]. Roslan J., Yunos K.F.M., Abdullah N., Mazlina S., and Kamal M., Characterization of Fish Protein Hydrolysate from Tilapia (Oreochromis niloticus) by-Product. Agriculture and Agricultural Science Procedia. 2, 312319 (2014).

[12]. Vo T.D.L., Nguyen T.T.H., Phan D.V., Nguyen H.D.M., and Tran H.Q., Investigation of antioxidant activity of the hydrolysate derived from Tra catfish by-products using Alcalase ${ }^{\circledR}$ 2.4L FG for application as a natural antioxidant ingredient. Journal of Science \& Technology Development. K6, 110-118 (2016).

[13]. Amiza M.A., Ashikin S.N., and Faazaz A.L., Optimization of enzymatic protein hydrolysis from silver catfsh (Pangasius sp.) frame. International Food Research Journal. 18, 775-781 (2011).

[14]. Aspmo S.I., Horn S.J., and Eijsink V.G.H., Enzymatic hydrolysis of Atlantic cod (Gadus morhua L.) viscera. Process Biochemistry. 40, 1957-1966 (2005).

[15]. Valencia P., Pinto M., and Almonacid S., Identification of the key mechanisms involved in the hydrolysis of fish protein by Alcalase. Process Biochemistry. 49(2), 258264 (2014).

[16]. Gbogouri G.A., Linder M., Fanni J., and Parmentier M., Influence of Hydrolysis Degree on the functional Properties of Salmon Byproducts Hydrolysates. Journal of Food Science. 69(8), C615-C622 (2004).

[17]. Ovissipour M., Abedian A., Motamedzadegan A., Rasco B., Safari R., and Shahiri H., The effect of enzymatic hydrolysis time and temperature on the properties of protein hydrolysates from Persian sturgeon (Acipenser persicus). Food Chemistry. 115, 238-242 (2009).

[18]. Kechaou E.S., Dumay J., Donnay-Moreno C., Jaouen P., Gouygou J.-P., Bergé J.-P., and Amar R.B., Enzymatic hydrolysis of cuttlefish (Sepia officinalis) and sardine (Sardina pilchardus) viscera using commercial proteases: Effects on lipid distribution and amino acid composition. Journal of Bioscience and Bioengineering. 107(2), 158164 (2009).

[19]. Phiraphinyo P., Taepakpurenat S., Lakkanatinaporn P., Suntornsuk W., and Suntornsuk L., Physical and chemical properties of fish and chicken bones as calcium source for mineral supplements. Journal of Food Science and Technology. 28(2), 327-335 (2006).

[20]. Botta J.R., Evaluation of Seafood Freshness Quality. 1995, New York: John Wiley \& Sons. 180.

[21]. Sun X.D. and Holley R.A., Factors Influencing Gel Formation by Myofibrillar Proteins in Muscle Foods. Comprehensive Reviews in Food Science and Food Safety. 10(1), 33-51 (2011).

Tam Dinh-Le Vo works for the division of Food Technology, Faculty of Chemical Engineering, Ho Chi Minh City University of Technology - Viet Nam National University Ho Chi Minh City, Vietnam (email: vdlt@hcmut.edu.vn)

Bao Chi Vo, Huynh Thi Thuy Nguyen, Linh Truc Le and Vi Thong Trong Do are students at Ho Chi Minh city University of Technology Vietnam National University-Ho Chi Minh City.

Thao Thi Huong Nguyen works for Research Center for Aquafeed Nutrition and Fishery Post harvest Technology, Research Institute for Aquaculture No.2. 


\title{
Thu nhận bột xương từ phụ phẩm cá hồi và ứng dụng trong sản xuất chả cá tra
}

\author{
Võ Đình Lệ Tâm*, Võ Chí Bảo, Nguyễn Thị Thúy Huỳnh, Lê Trúc Linh, \\ Đỗ Thông Trọng Vi, Nguyễn Thị Hương Thảo \\ Trường Đại học Bách khoa, ĐHQG-HCM \\ Tác giả liện hệ: vdlt@hcmut.edu.vn
}

Ngày nhận bản thảo: 06-12-2016, ngày chấp nhận đăng: 17-2-2017

Tóm tắt-Trong nghiên cứu này, phụ phẩm cá hồi được sử dụng để sản xuất bột xương giàu tro sử dụng chế phẩm enzyme và ứng dụng trong sản xuất chả cá tra. Thành phần hóa học phụ phẩm gồm có $61,9 \%$ ẩm, $43,1 \%$ protein, $45,4 \%$ chất béo, $10,2 \%$ tro, $3,7 \%$ canxi và $2,3 \%$ phospho (tính theo hàm lượng chất khô). Hàm lượng tro của bột xương đạt giá trị cao nhất 46,9\% khi sử enzyme thủy phân là Alcalase, nhiệt độ $600 \mathrm{C}, \mathrm{pH}$ 6,5, tỷ lệ enzyme/cơ chất $60 \mathrm{U} / g$ protein và thời gian thủy phân là 4 giờ. Bột xương thu được chứa $23,1 \%$ canxi, $11,7 \%$ phospho và không chứa các kim loại nặng như cadimi, thủy ngân và chì. Mẫu chả cá bổ sung $2 \%$ bột xương có độ chắc, độ uốn lát và độ trắng cao nhất với các giá trị lần lượt là $287,4, \mathrm{AA}$ và 65,3 và được chấp nhận bởi hội đồng đánh giá cảm quan. Vì vậy, bột xương thu nhận từ phụ phẩm cá hồi có thể được sử dụng để bổ sung vào chả cá tra như một nguồn khoáng bổ sung.

Tù khóa-bột xương cá hồi, hàm lượng tro, chả cá tra, canxi, phospho. 